\title{
OPTIMASI PROSES FINISHING KULIT IKAN NILA (Oreochromis niloticus) UNTUK BAGIAN ATAS SEPATU
}

\section{OPTIMATION OF TILAPIA (Oreochromis niloticus) FISH SKIN FINISHING PROCESS FOR SHOE UPPER}

\author{
Emiliana Kasmudjiastuti \\ Balai Besar Kulit, Karet, dan Plastik, Jl.Sokonandi No. 9 Yogyakarta 55166, Indonesia \\ Telp.: +62 274 512929, 563939; Fax.: +62 274 563655; \\ E-mail: emil_bbkkp@yahoo.com
}

Diterima: 20 Agustus 2014 Direvisi: 7 November 2014 Disetujui: 10 November 2014

\begin{abstract}
The aims of this study was to get the optimum finishing formulations of tilapia fish skin for shoe upper. The variations of experiment were four factors, namely of the variation of binders (1:2 and 1:3), lacquer water (1:1 and 1:2), plating temperatures $\left(50,65,80\right.$ and $\left.95^{\circ} \mathrm{C}\right)$ and plating time $(0.5,1$, and 1.5 seconds). Testing was conducted on tensile strength, elongation at break, tear strength, stitch strength, softness, and colour fastness. Statistical analysis was conducted using the General Linear Model (GLM) followed by Tukey's Studentized Range Test (TSRT). The results showed that the optimum formula for finishing were performed by a variation of binder $1: 2$, lacquer water 1:2, temperature of plating $95^{\circ} \mathrm{C}$ and time of plating 1.5 seconds, and it was characterized by the physical properties of tensile strength $177.32 \mathrm{~kg} / \mathrm{cm}^{2}$, elongation at break $62 \%$, tear strength $41.92 \mathrm{~kg} / \mathrm{cm}$, stitch strength $113.06 \mathrm{~kg} / \mathrm{cm}$, softness 2.33 and generally met the standard requirements of SNI 0253:2009: Footwear upper leather - goat skin.
\end{abstract}

Keywords: tilapia fish skin, aqueous top coat, leather finishing.

\begin{abstract}
ABSTRAK
Penelitian ini bertujuan untuk mendapatkan formulasi optimum untuk finishing kulit ikan nila sebagai bagian atas sepatu. Variasi perlakuan dalam percobaan terdiri atas empat faktor yaitu variasi binder (1:2 dan 1:3), lak air (1:1 dan 1:2), suhu plating $\left(50,65,80\right.$, dan $\left.95^{\circ} \mathrm{C}\right)$, dan waktu plating $(0,5 ; 1 ;$ dan 1,5 detik). Parameter mutu sampel meliputi uji kekuatan tarik, kemuluran, kekuatan sobek, kekuatan jahit, kelemasan, dan ketahanan gosok cat. Analisis statistik menggunakan General Linier Model (GLM) dilanjutkan dengan uji Tukey's Studentized Range Test (TSRT). Hasil penelitian menunjukkan bahwa formula optimum untuk finishing diperoleh dari perlakuan penggunaan binder 1: 2, lak air 1: 2, suhu plating $95^{\circ} \mathrm{C}$ dan waktu plating 1,5 detik. Bagian atas sepatu tersebut memiliki kekuatan tarik 177,32 kg/ $\mathrm{cm}^{2}$, kemuluran $62 \%$, kekuatan sobek 41,92 kg/cm, kekuatan jahit 113,06 kg/ $\mathrm{cm}$, kelemasan 2,33 dan secara umum parameter mutu bagian atas sepatu kulit ikan nila memenuhi persyaratan SNI 0253:2009 Kulit bagian atas alas kaki - kulit kambing.
\end{abstract}

Kata kunci: kulit ikan nila, aqueous top coat, finishing kulit.

\section{PENDAHULUAN}

Proses finishing (penyempurnaan) kulit adalah merupakan tahapan akhir pada pengolahan/ penyamakan kulit, yang menjadikan kulit berpenampilan menarik dan comfortable untuk pembuatan ragam produk jadi kulit (Sah, 2013). Tujuan finishing adalah untuk melindungi permukaan kulit terhadap kerusakan karena air, tanah, perlakuan mekanis, dan untuk memperbaiki sifatsifat fisika seperti ketahanan gosok cat, ketahanan terhadap sinar, memberikan lapisan tipis/film pada permukaan kulit yang cacat, memberikan rajah buatan untuk kulit split atau corrected grain dan memodifikasi sifat-sifat permukaan (BASF, 2009). Perlakuan untuk finishing berbeda-beda tergantung tujuan dan kondisi permukaan kulit yang diolah. Finishing kulit dilakukan dengan perlakuan fisik, pemberian bahan kimia/aplikasi larutan pada permukaan kulit, dan dilanjutkan dengan perlakuan mekanik seperti plating, em- 
bossing dan glazing agar kulit sebagai hasil akhir berpenampilan menarik dan berkualitas.

Secara normal finishing kulit terdiri atas 3 lapisan yaitu lapisan dasar (base coat), lapisan tengah (middle coat/pigment coat) dan lapisan atas (top coat) (Sah, 2013). Coating merupakan tahap penting pada proses finishing yang berfungsi untuk melindungi permukaan kulit dari pengaruh luar (Lanxees, 2011). Formulasi untuk finishing kulit berbeda-beda tergantung pada sifat-sifat kulit yang diinginkan misalnya untuk jaket, jok, atau bagian atas sepatu. Bahan-bahan untuk finishing meliputi pigmen, binder, waxes, pengawet, plasticizer, thickener, filler, dan penetrator.

Binder adalah kompon makromolekul pembentuk film (lapis tipis) yang dapat memberikan lapisan pada kulit, kelenturan, kerekatan, dan ketahanan terhadap faktor-faktor eksternal selama pemakaian kulit. Binder digunakan dalam komposisi sistem finishing kulit yang natural seperti akrilik, poliuretan, butadiena, dan binder protein dengan ukuran partikel dan derajat kekerasan yang berbeda untuk mendapatkan hasil akhir yang diinginkan (glossy, matte), karakteristik fisik dan mekanik seperti kekuatan tarik, kemuluran, kekuatan sobek, dan ketahanan gosok cat (Niculescu et al., 2012). Binder akrilik mempunyai sifat flexibility dan soft feel, sedang binder poliuretan hampir sama dengan binder akrilik tetapi sentuhan (touch) lebih keras dan lebih awet (Hoefler et al., 2013). Binder butadiena mempunyai daya menutup yang tinggi akan tetapi ketahanan sinar kurang baik (high covering power dan light fastness is poor). Binder protein merupakan binder non-termoplastik seperti kasein, albumin, gelatin, dan poliamida sintetis. Top coat untuk finishing kulit yang digunakan secara tradisional adalah solvent based nitrocellulose (NC) dan cellulose acetate butyrate (CAB) lacquer. Sekarang telah banyak digunakan secara luas aqueous top coat. Penggunaan aqueous top coat dahulu hanya untuk kulit jok saja tetapi sekarang banyak digunakan untuk kulit atasan sepatu, meskipun solvent based top coat juga masih digunakan untuk artikel tertentu. Penggunaan aqueous top coat selain dapat mengurangi bahan berbahaya seperti NMP (N-Methylpyrrolidone) juga mendukung konsep berkelanjutan (sustainability). Solvent based top coat disinyalir dapat menimbulkan masalah lingkungan karena terjadinya migrasi pelarut dari kulit setelah pengeringan dan dalam periode waktu lama terutama pada kondisi kenaikan suhu (Blach et al., 2012). Kon- sep berkelanjutan dan ramah lingkungan perlu ditingkatkan dengan peraturan lingkungan yang ketat antara lain melakukan pembatasan penggunaan solvent based coating (Lanxees, 2011). Salah satu "ingredients" yang digunakan untuk aqueous top coat adalah lak air (Kabeer, 2014). Top coat menentukan kenampakan akhir dari kulit seperti pegangan (handle) dan pengaruhnya terhadap sifat-sifat fisis dan ketahanan terhadap gosokan (Gulbiniene et al., 2003).

Untuk finishing kulit reptil dan ikan, biasanya tipe bahan finishing yang digunakan adalah tipe finish anilin yaitu tanpa menggunakan pigmen, desain permukaan dapat dipertahankan. Kulit yang mengalami finishing dengan anilin akan tampak natural dengan karakteristik permukaan yang unik (Gulbiniene et al., 2003).

Menurut Suryaningsih dkk. (2007) penyamakan kulit ikan nila GIFT berpotensi untuk dikembangkan penggunaanya sebagai barang kulit seperti sepatu dengan penampilan khas, dan mutu kulit hasil finishingnya perlu ditingkatkan agar tampilan ciri khas kulit ikan tersebut lebih dapat dinikmati keindahannya, dan memenuhi persyaratan mutu untuk kulit bagian atas sepatu. Penelitian lain terkait kulit ikan nila telah banyak dilakukan diantaranya tentang pengaruh zat warna reaktif terhadap sifat ketahanan luntur warna dan morfologi kulit ikan nila untuk garmen (Kasmudjiastuti, 2011), pemanfaatan limbah kulit ikan nila dari industri filet untuk kulit jaket (Prayitno dkk., 2012) dan pengaruh jumlah minyak terhadap sifat fisis kulit ikan nila untuk bagian atas sepatu (Pahlawan \& Kasmudjiastuti, 2012).

Pada penelitian ini fokus penelitian pada proses finishing terutama pada lapisan atas (top coat) dengan variasi binder protein dan lak air serta proses plating dengan variasi suhu dan waktu. Dari hasil penelitian ini diharapkan dapat diketahui perbandingan pemakaian binder protein dan lak air serta besarnya suhu dan waktu plating yang optimal, untuk finishing kulit bagian atas sepatu.

Tujuan penelitian adalah untuk mengetahui formula optimum finishing kulit ikan nila untuk pembuatan bagian atas sepatu.

\section{BAHAN DAN METODE \\ Bahan Penelitian}

Bahan penelitian terdiri atas bahan baku dan bahan kimia. Bahan baku berupa kulit ikan nila kering dari distributor kulit ikan nila di Surakarta. Bahan kimia untuk proses penyamakan dan finish- 
ing kulit meliputi $\mathrm{NaHCO}_{3}$, tepol, $\mathrm{Ca}(\mathrm{OH})_{2}, \mathrm{Na}_{2} \mathrm{~S}$, $\mathrm{NH}_{4} \mathrm{Cl}$, Oropon OR, $\mathrm{NaCl}$, Tergolix A, $\mathrm{HCOOH}$, $\mathrm{H}_{2} \mathrm{SO}_{4}$, Tanigan PAK, Tanigan HO, Tanigan OS, Novaltan PF, Chromosal B, P100, minyak sulfonasi, cat asam, Preventol, binder protein, dan lak air. Semua bahan kimia yang digunakan diperoleh dari distributor bahan kimia di Yogyakarta.

\section{Peralatan Penelitian}

Alat penelitian terdiri atas wadah plastik (ember) kapasitas 5 liter, timbangan analitik, papan pentangan, spray gun, alat peregang manual (Hand Staking) terbuat dari lempeng baja diameter 20 $\mathrm{cm}$. Mesin seterika (ironing) Mostardini, alat uji tensile strength merk Kao Tieh model KT 7010 A untuk menguji kuat tarik, kemuluran dan kekuatan sobek serta crockmeter.

\section{Metode Penelitian}

\section{Finishing kulit ikan nila}

Dalam penelitian ini variable yang dipelajari dalam finishing bagian atas sepatu dengan sistem aqueous top coat (water based) meliputi 4 (empat) faktor perlakuan yaitu: variasi binder (kode A (1:2) dan kode B (1:3)), lak air (kode C (1:1), kode D $(1: 2)$ ), suhu plating (kode I $\left(50^{\circ} \mathrm{C}\right)$, kode II $\left(65^{\circ} \mathrm{C}\right)$, kode III $\left(80^{\circ} \mathrm{C}\right)$, kode IV $\left(95^{\circ} \mathrm{C}\right)$, dan waktu plating (kode a ( 0,5 detik), kode $\mathrm{b}$ (1 detik), kode $\mathrm{c}$ (1,5 detik)). Proses penyamakan secara umum menggunakan metode standar proses penyamakan kulit ikan dari Laboratorium Riset Penyamakan Kulit di Balai Besar Kulit, Karet dan Plastik (BBKKP) Yogyakarta dan tahap finishing kulit ikan nila untuk bagian atas sepatu disajikan pada Gambar 1.

\section{Uji parameter mutu bagian atas sepatu kulit ikan nila dan analisis data}

Uji parameter mutu bagian atas sepatu kulit ikan nila meliputi kekuatan tarik, kemuluran, kekuatan sobek, dan ketahanan gosok cat dengan mengikuti prosedur dalam SNI. 0253:2009 Kulit bagian atas alas kaki-kulit kambing, dan uji kelemasan dan kekuatan jahit (BSN, 2009). Data yang diperoleh dari hasil uji dianalisis secara statistik menggunakan prosedur General Linier Model (GLM) dan uji lanjut untuk mengetahui beda nyata antar perlakuan digunakan Tukey's Studentized Range Test (TSRT) (Sarwono, 2013).

\section{HASIL DAN PEMBAHASAN Kekuatan Tarik}

Analisis statistik dengan prosedur GLM menunjukkan bahwa tidak berbeda nyata $(\mathrm{p} \geq 0,05)$ pada pemakaian binder 1:2 dan 1:3, penggunaan suhu plating berturut-turut $50,65,80$, dan $95^{\circ} \mathrm{C}$. Namun terdapat beda nyata $(\mathrm{p} \leq 0,05)$ pada perlakuan penggunaan lak air 1:1 dan 1:2 dan penggunaan waktu plating berturut-turut 0,$5 ; 1,0$; dan 1,5 detik. Berarti bahwa variasi penggunaan lak air
Faktor 1: Variasi binder protein, (1:2) dan (1:3)

Faktor 2: Variasi lak air, $(1: 1)$ dan $(1: 2)$

Faktor 3: Variasi suhu, $\left(50,65,80\right.$, dan $\left.95^{\circ} \mathrm{C}\right)$ Faktor 4:Variasi waktu $(0,5 ; 1$; dan 1,5 detik)

Kulit kras warna dari

kulit ikan nila

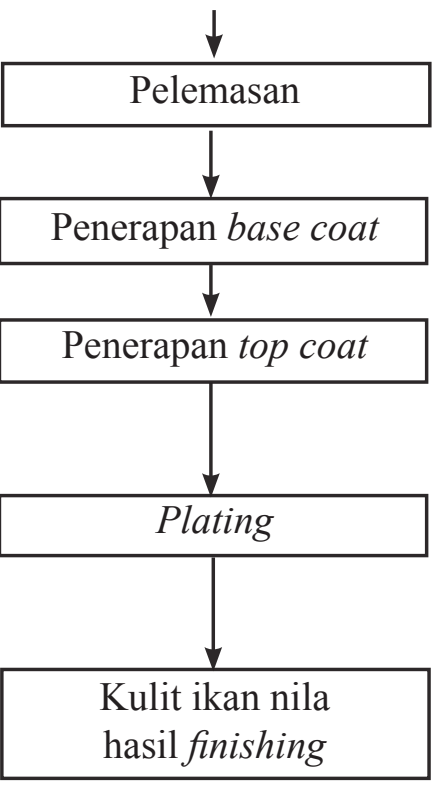

Alat hand staking

Alat spray gun (spray 2X)

Alat spray gun (spray 2X)

Mesin ironing

Gambar 1. Tahap finishing kulit ikan nila untuk bagian atas sepatu. 
dan waktu plating mempengaruhi nilai kekuatan tarik kulit ikan nila.

Hasil analisis GLM menunjukkan tidak ada interaksi antar pengaruh penggunaan binder, lak air, suhu plating serta penggunaan lak air dan waktu plating terhadap kekuatan tarik dan ada interaksi antara faktor 1 dan 2, faktor 1 dan 3, faktor 2 dan 3 , faktor 1 dan 4 , faktor 1,2 , dan 4 , faktor 3 dan 4, faktor 1, 3, dan 4, faktor 1, 2, 3, dan 4 terhadap kekuatan tarik. Hasil uji GLM kemudian diuji dengan TSRT dan hasilnya seperti ditunjukkan pada Tabel 1.

Berdasarkan hasil analisis dengan prosedur GLM dinyatakan bahwa terdapat interaksi antara faktor $1,2,3$, dengan 4 . Tabel 1 menunjukkan bahwa nilai kekuatan tarik tertinggi diperoleh dari faktor 1 yaitu penggunaan binder (1:3), faktor 2 penggunaan lak air (1:2), faktor 3 pada suhu plating $95^{\circ} \mathrm{C}$ dan faktor 4 waktu plating 1 detik sehingga kekuatan tarik optimal kulit ikan nila hasil penelitian ini adalah dengan finishing menggunakan binder 1:3, lak air 1:2, plating pada suhu $95^{\circ} \mathrm{C}$ selama 1 detik yaitu sebesar $155,45 \mathrm{~kg} /$ $\mathrm{cm}^{2}$.

Plating membantu meratakan lapisan atau film yang terbentuk (good levelling of the film) dan secara umum ketahanan warna (fastness) meningkat dan lapisan yang terbentuk menjadi kompak dan permanen. Biasanya untuk plating lazim dilakukan pada suhu diatas $80^{\circ} \mathrm{C}$. Parameter mutu plating dan embossing yang digunakan adalah waktu, suhu dan tekanan, yang semuanya merupakan faktor penentu untuk memobilisasi energi perekatan film pada permukaan kulit.

\section{Kemuluran}

Analisis statistik dengan GLM, menunjukkan bahwa terdapat beda nyata $(\mathrm{p} \leq 0,05)$ pada pemakaian binder 1:2 dan 1:3, dan penggunaan suhu plating berturut-turut $50,65,80$, dan $95^{\circ} \mathrm{C}$. Hal ini kemungkinan karena perbandingan pemakaian binder dan suhu plating sudah cukup memadai, sehingga berpengaruh terhadap nilai kemuluran. Menurut Niculescu (2012), bahwa penggunaan binder dalam komposisi finishing mempengaruhi kekuatan sobek. Selanjutnya pada penggunaan lak air 1:1 dan 1:2 dan pada waktu plating berturutturut 0,$5 ; 1,0 ;$ dan 1,5 detik, menunjukkan tidak berbeda nyata $(p \geq 0,05)$.

Hasil analisis GLM juga menunjukkan interaksi antara faktor 3 dan 4 , tetapi tidak ada interaksi antara faktor 1 dan 2; faktor 1 dan 3; faktor 2 dan 3; faktor 1, 2, dan 3; faktor 1 dan 4; faktor 2 dan 4; faktor 1, 2, dan 4; faktor 1, 3, dan 4; dan faktor 1, 2, 3, dan 4 terhadap kemuluran kulit ikan nila.

Hasil analisis GLM kemudian dilanjutkan uji TSRT dan hasilnya seperti ditunjukkan pada Tabel 2. Berdasarkan hasil analisis dengan prosedur GLM dinyatakan bahwa terdapat interaksi antara faktor 3 dan 4. Tabel 2 menunjukkan bahwa nilai kemuluran terendah diperoleh dari faktor 1 yaitu penggunaan binder (1:2), faktor 2 penggunaan lak air (1:2), dan pada faktor 3 perbandingan yang signifikan yaitu antara penggunaan suhu plating 95 dan $50^{\circ} \mathrm{C}$ dan pada faktor 4 perbandingan yang signifikan waktu plating 1,5 dan 0,5 detik sehingga kemuluran optimal kulit ikan nila hasil penelitian ini adalah dengan finishing menggunakan binder 1:2, lak air 1:2, plating pada suhu $95^{\circ} \mathrm{C}$ selama 1,5 detik yaitu sebesar $62 \%$.

\section{Kekuatan Sobek}

Analisis statistik dengan prosedur GLM menunjukkan bahwa terdapat beda nyata $(\mathrm{p} \leq 0,05)$ pada pemakaian binder $1: 2$ dan $1: 3$, penggunaan lak air $1: 1$ dan $1: 2$, penggunaan suhu plating berturut-turut $50,65,80$, dan $95^{\circ} \mathrm{C}$, penggunaan waktu plating berturut-turut 0,$5 ; 1,0$; dan 1,5 detik. Hal ini berarti bahwa variasi penggunaan binder,

Tabel 1. Tukey's Studentized Range Test (TSRT) kekuatan tarik $\left(\mathrm{kg} / \mathrm{cm}^{2}\right)$ kulit ikan nila*)

\begin{tabular}{|c|c|c|c|}
\hline $\begin{array}{c}\text { Rasio binder } \\
\text { (A } 1: 2, \mathrm{~B} 1: 3) \\
\mathrm{A}=\mathrm{B}\end{array}$ & $\begin{array}{c}\text { Rasio lak air } \\
(\mathrm{C} 1: 1, \mathrm{D} 1: 2) \\
\text { C } \neq \mathrm{D}\end{array}$ & $\begin{array}{c}\text { Suhu plating }\left({ }^{\circ} \mathrm{C}\right) \\
(\mathrm{I} 50, \mathrm{II} 65, \mathrm{III} 80, \mathrm{IV} 95) \\
\mathrm{I}=\mathrm{II}=\mathrm{III}=\mathrm{IV}\end{array}$ & $\begin{array}{c}\text { Waktu plating (detik) } \\
\begin{array}{c}(\mathrm{a} 0,5 ; \mathrm{b} 1 ; \mathrm{c} 1,5) \\
\mathrm{a} \neq \mathrm{b} \neq \mathrm{c}\end{array}\end{array}$ \\
\hline B $123,83^{\left.\mathrm{A}^{* *}\right)}$ & D $127,49^{A}$ & IV $130,00^{\mathrm{A}}$ & b $129,94^{A}$ \\
\hline \multirow[t]{3}{*}{ A $119,55^{\mathrm{A}}$} & C $115,88^{\text {в }}$ & I $122,34^{\mathrm{A}}$ & a $122,58 \mathrm{AB}$ \\
\hline & & II $119,67^{A}$ & c $112,54^{\mathrm{A}}$ \\
\hline & & III $114,74^{\mathrm{A}}$ & \\
\hline
\end{tabular}

*) Rata-rata dari 3 ulangan sampel dengan 3 ulangan analisis

**) Huruf sama dibelakang angka pada kolom sama menunjukkan tidak ada beda nyata $(\mathrm{p} \geq 0,05)$ 
lak air, suhu dan waktu plating berpengaruh terhadap kekuatan sobek. Berdasarkan hasil uji GLM juga menunjukkan bahwa dijumpai interaksi antara faktor 1 dan 2; faktor 2 dan 3; faktor 1, 2, dan 3; faktor 1 dan 4; faktor 2 dan 4; faktor 1, 2 dan 4; faktor 3 dan 4; faktor 1, 3, dan 4; faktor 2, 3, dan 4 dan faktor 1, 2, 3, dan 4 tetapi tidak dijumpai interaksi antara faktor 1 dan 3 .

Hasil uji GLM kemudian dilanjutkan TSRT dan hasilnya seperti ditunjukkan pada Tabel 3. Berdasarkan hasil uji dengan prosedur GLM dinyatakan bahwa terdapat interaksi antara faktor 1 , 2, 3 dan 4. Tabel 3 menunjukkan bahwa kekuatan sobek tertinggi diperoleh dari perlakuan faktor 1 yaitu penggunaan binder (1:2), faktor 2 penggunaan lak air (1:2), pada faktor 3 perbandingan yang signifikan antara penggunaan suhu plating $95^{\circ} \mathrm{C}$ dan $50^{\circ} \mathrm{C}$ dan faktor 4 perbandingan yang signifikan antara waktu plating 1,5 dan 1,0 detik, sehingga kekuatan sobek optimal kulit ikan nila hasil penelitian ini adalah dengan finishing menggunakan binder 1:2, lak air 1:2, plating pada suhu $95^{\circ} \mathrm{C}$ selama 1,5 detik yaitu sebesar $41,92 \mathrm{~kg} / \mathrm{cm}$.

\section{Kekuatan Jahit}

Analisis statistik dengan prosedur GLM menunjukkan bahwa terdapat beda nyata $(\mathrm{p} \leq 0,05)$ antara penggunaan suhu plating berturut-turut 50 , 65,80 , dan $95^{\circ} \mathrm{C}$, dan penggunaan waktu plating berturut-turut 0,$5 ; 1,0$; dan 1,5 detik. Hal ini berarti bahwa variasi suhu dan waktu plating berpenga- ruh terhadap kekuatan jahit bahan atau sampel. Selanjutnya faktor 1 pemakaian binder 1:2 dan 1:3, dan faktor 2 penggunaan lak air 1:1 dan 1:2 menunjukkan tidak berbeda nyata $(p \geq 0,05)$.

Hasil uji GLM juga menunjukkan interaksi antara faktor 1 dan 2; faktor 2 dan 3; faktor 3 dan 4; faktor 1, 3, dan 4; faktor 2, 3, dan 4 tetapi tidak terdapat interaksi antara faktor 1 dan 3; faktor 1, 2 dan 3; faktor 1 dan 4; faktor 2 dan 4; faktor 1, 2 dan 4; serta faktor 1, 2, 3, dan 4. Hasil analisis GLM kemudian dilanjutkan TSRT dan hasilnya seperti ditunjukkan pada Tabel 4.

Hasil uji dengan prosedur GLM dinyatakan bahwa terdapat interaksi antara faktor 2, 3, dan 4 serta faktor 1, 3, dan 4. Tabel 4 menunjukkan bahwa nilai kekuatan jahit tertinggi pada faktor 1 adalah penggunaan binder (1:2), faktor 2 adalah penggunaan lak air (1:2), pada faktor 3 perbandingan yang signifikan yaitu antara penggunaan suhu plating $95^{\circ} \mathrm{C}$ dan $50^{\circ} \mathrm{C}$ dan pada faktor 4 perbandingan yang signifikan yaitu antara penggunaan waktu plating 1,5 detik dan 1,0 detik sehingga kekuatan jahit optimal kulit ikan nila hasil penelitian ini adalah dengan finishing menggunakan binder $1: 2$, lak air $1: 2$, plating pada suhu $95^{\circ} \mathrm{C}$ selama 1,5 detik yaitu sebesar $113,06 \mathrm{~kg} / \mathrm{cm}$.

\section{Kelemasan}

Analisis statistik dengan prosedur GLM menunjukkan bahwa terdapat beda nyata $(\mathrm{p} \leq 0,05)$ pada penggunaan suhu plating berturut-turut 50 ,

Tabel 2. Tukey's Studentized Range Test (TSRT) kemuluran (\%) kulit ikan nila*)

\begin{tabular}{|c|c|c|c|}
\hline $\begin{array}{c}\text { Rasio binder } \\
(\mathrm{A} 1: 2, \mathrm{~B} 1: 3) \\
\mathrm{A} \neq \mathrm{B}\end{array}$ & $\begin{array}{l}\text { Rasio lak air } \\
(\mathrm{C} 1: 1, \mathrm{D} 1: 2) \\
\mathrm{C}=\mathrm{D}\end{array}$ & $\begin{array}{c}\text { Suhu plating }\left({ }^{\circ} \mathrm{C}\right) \\
\text { ( I 50, II } 65, \text { III } 80, \text { IV 95) } \\
\text { I } \neq \text { II } \neq \text { III } \neq \text { IV }\end{array}$ & $\begin{array}{l}\text { Waktu plating (detik) } \\
\qquad \begin{array}{c}\text { (a } 0,5 ; \mathrm{b} 1 ; \mathrm{c} 1,5) \\
\mathrm{a}=\mathrm{b}=\mathrm{c}\end{array}\end{array}$ \\
\hline A $69,52^{\left.\mathrm{B}^{* *}\right)}$ & $\mathrm{D} 70,78^{\mathrm{A}}$ & IV - I & $c-a$ \\
\hline B $75,27^{\mathrm{A}}$ & C $74,19^{A}$ & & \\
\hline
\end{tabular}

*) Rata-rata dari 3 ulangan sampel dengan 3 ulangan analisis

**) Huruf sama dibelakang angka pada kolom sama menunjukkan tidak ada beda nyata $(\mathrm{p} \geq 0,05)$

Tabel 3. Tukey's Studentized Range Test (TSRT) kekuatan sobek (kg/cm) kulit ikan nila*)

\begin{tabular}{cccc}
\hline $\begin{array}{c}\text { Rasio Binder (A } \\
1: 2, \mathrm{~B} 1: 3)\end{array}$ & $\begin{array}{c}\text { Rasio Lak air } \\
\text { (C } 1: 1, \mathrm{D} 1: 2)\end{array}$ & $\begin{array}{c}\text { Suhu plating }\left({ }^{\circ} \mathrm{C}\right) \\
(\mathrm{I} 50, \mathrm{II} 65, \mathrm{III} 80, \mathrm{IV} 95)\end{array}$ & $\begin{array}{c}\text { Waktu plating (detik) } \\
(\mathrm{a} 0,5 ; \mathrm{b} 1 ; \mathrm{c} 1,5) \\
\mathrm{a} \neq \mathrm{b} \neq \mathrm{c}\end{array}$ \\
\hline $\mathrm{A} 34,07^{\mathrm{A} * *}$ & D $35,55^{\mathrm{A}}$ & IV $-\mathrm{I}$ & $\mathrm{c}-\mathrm{b}$ \\
$\mathrm{B} 33,38^{\mathrm{A}}$ & C $31,82^{\mathrm{A}}$ & & \\
\hline
\end{tabular}

*) Rata-rata dari 3 ulangan sampel dengan 3 ulangan analisis

**) Huruf sama dibelakang angka pada kolom sama menunjukkan tidak ada beda nyata $(p \geq 0,05)$ 
Tabel 4. Tukey's Studentized Range Test (TSRT) kekuatan jahit (kg/cm) kulit ikan nila*)

\begin{tabular}{|c|c|c|c|}
\hline $\begin{array}{c}\text { Rasio Binder (A } \\
1: 2, \mathrm{~B} 1: 3) \\
\mathrm{A}=\mathrm{B}\end{array}$ & $\begin{array}{l}\text { Rasio lak air } \\
(\text { C } 1: 1, \text { D } 1: 2) \\
\text { C }=\text { D }\end{array}$ & $\begin{array}{c}\text { Suhu plating }\left({ }^{\circ} \mathrm{C}\right) \\
\text { ( I } 50, \text { II } 65, \text { III } 80 \text {, dan IV 95) } \\
\text { I } \neq \text { II } \neq \text { III } \neq \text { IV }\end{array}$ & $\begin{array}{l}\text { Waktu plating (detik) } \\
\qquad \begin{array}{c}\text { (a } 0,5 ; \mathrm{b} 1 ; \mathrm{c} 1,5) \\
\mathrm{a} \neq \mathrm{b} \neq \mathrm{c}\end{array}\end{array}$ \\
\hline A $85,40^{\left.\mathrm{A}^{* *}\right)}$ & D $85,25^{\left.\mathrm{A}^{* *}\right)}$ & IV - I & $c-b$ \\
\hline B $82,90^{A}$ & C $83,94^{\mathrm{A}}$ & & \\
\hline
\end{tabular}

*) Rata-rata dari 3 ulangan sampel dengan 3 ulangan analisis

**) Huruf sama dibelakang angka pada kolom sama menunjukkan tidak ada beda nyata $(p \geq 0,05)$

Tabel 5. Tukey's Studentized Range Test (TSRT) kelemasan kulit ikan nila*)

\begin{tabular}{|c|c|c|c|}
\hline $\begin{array}{c}\text { Rasio Binder (A } \\
1: 2, \mathrm{~B} 1: 3) \\
\mathrm{A}=\mathrm{B}\end{array}$ & $\begin{array}{c}\text { Rasio Lak air } \\
(\mathrm{C} 1: 1, \mathrm{D} 1: 2) \\
\mathrm{C}=\mathrm{D}\end{array}$ & $\begin{array}{c}\text { Suhu plating }\left({ }^{\circ} \mathrm{C}\right) \\
\text { ( I 50, II } 65, \text { III } 80, \text { IV 95) } \\
\text { I } \neq \text { II } \neq \text { III } \neq \text { IV }\end{array}$ & $\begin{array}{l}\text { Waktu plating (detik) } \\
\qquad \begin{array}{c}\text { (a } 0,5 ; \mathrm{b} 1 ; \mathrm{c} 1,5) \\
\mathrm{a} \neq \mathrm{b} \neq \mathrm{c}\end{array}\end{array}$ \\
\hline A $85,40^{\left.\mathrm{A}^{* *}\right)}$ & D $85,25^{\left.\mathrm{A}^{* *}\right)}$ & I - II & $a-b$ \\
\hline B $82,90^{A}$ & C $83,94^{A}$ & & \\
\hline
\end{tabular}

*) Rata-rata dari 3 ulangan sampel dengan 3 ulangan analisis

**) Huruf sama dibelakang angka pada kolom sama menunjukkan tidak ada beda nyata $(\mathrm{p} \geq 0,05)$

65,80 , dan $95^{\circ} \mathrm{C}$, dan penggunaan waktu plating berturut-turut 0,$5 ; 1,0$; dan 1,5 detik. Hal ini menunjukkan bahwa variasi suhu dan waktu plating cukup memadai pengaruhnya terhadap kelemasan kulit ikan nila. Namun demikian tidak berbeda nyata $(p \geq 0,05)$ pada pemakaian binder $1: 2$ dan 1:3 dan penggunaan lak air 1:1 dan 1:2.

Hasil uji GLM juga menunjukkan interaksi antara faktor 1 dan 2; faktor 2 dan 3; faktor 3 dan 4; faktor 1, 3, dan 4; faktor 2, 3, dan 4 tetapi tidak terdapat interaksi antara faktor 1 dan 3; faktor 1,2 dan 3; faktor 1 dan 4; faktor 2 dan 4; faktor 1, 2 dan 4 serta faktor 1, 2, 3, dan 4. Hasil analisis GLM kemudian dilanjutkan TSRT dan hasilnya seperti ditunjukkan pada Tabel 5 .

Hasil analisis dengan prosedur GLM menyatakan bahwa terdapat interaksi antara faktor 2, 3 dan 4 serta faktor 1,3 , dan 4 . Tabel 5 menunjukkan bahwa nilai kelemasan tertinggi dijumpai faktor 1 penggunaan binder 1:2; faktor 2 penggunaan lak air 1:2, pada faktor 3 penggunaan suhu plating 50 dan $65^{\circ} \mathrm{C}$ dan faktor 4 waktu plating 0,5 dan 1,0 detik sehingga kelemasan optimal kulit ikan nila hasil penelitian ini adalah dengan finishing menggunakan binder 1:2, lak air 1:2, plating pada suhu $50^{\circ} \mathrm{C}$ selama 0,5 detik yaitu sebesar 3,32 .

\section{Ketahanan Gosok Cat}

Hasil analisis ketahanan gosok cat (kering, basah) pada penelitian ini untuk semua perlakuan, pada umumnya telah memenuhi persyaratan baik untuk ketahanan gosok cat (kering) rata-rata 4/5 dan ketahanan gosok cat (basah) antara 3/4-4. Hal ini berarti penggunaan larutan finishing dan variasi suhu dan waktu plating telah membentuk lapisan finishing pada kulit ikan nila dan tahan terhadap gosokan baik secara kering maupun basah. Kecuali untuk perlakuan plating pada suhu $50^{\circ} \mathrm{C}$ dan variasai waktu plating maka ketahanan gosoknya masih rendah yaitu 4 (kering) dan 3-3/4 (basah). Hal ini dapat disebabkan oleh penggunaan suhu untuk plating $50^{\circ} \mathrm{C}$, kemungkinan lapisan finishing yang terbentuk pada permukaan kulit ikan nila masih belum matang sehingga tidak tahan terhadap gosokan secara kering maupun basah. Plating sebenarnya untuk membantu meratakan lapisan yang terbentuk (good levelling of the film) dan secara umum ketahanan warna (fastness) meningkat dan lapisan yang terbentuk menjadi kompak dan permanen. Biasanya plating dengan suhu diatas $80^{\circ} \mathrm{C}$.

\section{KESIMPULAN}

Berdasarkan analisis statistik terhadap hasil uji fisik kulit ikan nila dapat disimpulkan sebagai berikut: Kekuatan tarik optimal dihasilkan dari penggunaan binder 1:3, lak air 1:2, plating pada suhu $95^{\circ} \mathrm{C}$ selama 1 detik sebesar $155,45 \mathrm{~kg} / \mathrm{cm}^{2}$, kemuluran optimal dihasilkan dari penggunaan binder $1: 2$, lak air $1: 2$, plating pada suhu $95^{\circ} \mathrm{C}$ selama 1,5 detik sebesar $62 \%$, kekuatan sobek optimal dihasilkan dari penggunaan binder 1:2, lak air 
$1: 2$, plating pada suhu $95^{\circ} \mathrm{C}$ selama 1,5 detik sebesar 41,92 kg/cm, kekuatan jahit optimal dihasilkan dari penggunaan binder 1:2, lak air 1:2, plating pada suhu $95^{\circ} \mathrm{C}$ selama 1,5 detik sebesar 113,06 $\mathrm{kg} / \mathrm{cm}$, kelemasan optimal dihasilkan dari penggunaan binder $1: 2$, lak $1: 2$, plating pada suhu $50^{\circ} \mathrm{C}$ selama 0,5 detik sebesar 3,32, ketahanan gosok cat yang baik (kering $4 / 5$, basah 3/4-4) adalah hasil plating pada suhu di atas $50^{\circ} \mathrm{C}\left(65-95^{\circ} \mathrm{C}\right)$ selama 0,5-1,5 detik, dan penggunaan binder (1:2 dan 1:3), dan lak (1:1 dan 1:2).

Kulit ikan nila untuk bagian atas sepatu terbaik berdasarkan 6 (enam) parameter mutu diperoleh dari rasio binder 1:2; rasio lak air 1:2; dan plating pada suhu $95^{\circ} \mathrm{C}$ selama 1,5 detik. Bagian atas sepatu tersebut memiliki kekuatan tarik $177,32 \mathrm{~kg} / \mathrm{cm}^{2}$, kemuluran $62 \%$, kekuatan sobek $41,92 \mathrm{~kg} / \mathrm{cm}$, kekuatan jahit $113,06 \mathrm{~kg} / \mathrm{cm}$, kelemasan 2,33 dan ketahanan gosok cat 4/5 (kering), 3/4 (basah). Secara umum sifat fisis kulit ikan nila tersebut telah memenuhi persyaratan SNI 0253:2009.

\section{UCAPAN TERIMA KASIH}

Ucapan terima kasih kami sampaikan kepada ibu Sri Untari, Heru Budi Susanto, Kasmin Nainggolan, Thomas Tukirin dan Marjito yang telah membantu dalam kegiatan penelitian ini.

\section{DAFTAR PUSTAKA}

BASF. (2009). Leather finishing manual. Ludwigshafen, Jerman: BASF.

Blach, R., Reineking, C., \& Schneider, R. (2012). Sustainability through the leather production chain. World Leather, Apr/Mei 2012.

BSN (Badan Standardisasi Nasional). (2009). SNI. 0253:2009 Kulit bagian atas alas kaki-kulit kambing. Jakarta, Indonesia: BSN.
Gulbiniene, A., Jankauskaite, V., \& Arcisauskaite, R. (2003). Effect of leather finishing on water vapour transmission. Part I: Water vapour transfer through pigment finish leather. Materials Science (Medziagotyra), 9(3), 275-280.

Hoefler, J., Hageman, B., Chung, C.J., \& Smith, R. (2013). High performance acrylic polymer technology for use in leather finishing process. Journal of American Leather Chemists Association, 108(8), 311-317.

Kabeer, S. S. A. S. (2014). Water based finishes for leather Products. India: STAHL.

Kasmudjiastuti, E. (2011). Pengaruh zat warna reaktif terhadap sifat ketahanan luntur warna dan morfologi kulit ikan nila (Tilapia nilotica) untuk garmen. Majalah Kulit, Karet dan Plastik, 27(1), $15-22$.

Lanxees. (2011). Launch water based transfer coating, Germany: Lanxess.

Niculescu, O., Leca, M., Coara, G., Macovescu, G., \& Chelaru, C. (2012). Characterization of coating aqueous disperse systems used in natural leather finishing. Revista Dechimie, 63(9), 900-905.

Pahlawan, I. F., \& Kasmudjiastuti, E. (2012). Pengaruh jumlah minyak terhadap sifat fisis kulit ikan nila untuk bagian atas sepatu. Majalah Kulit, Karet dan Plastik, 28(2), 105-111.

Prayitno, P., Kasmudjiastuti, E., \& Wachid, N. (2012). Pemanfaatan limbah kulit ikan nila dari industri filet untuk jaket. Majalah Kulit, Karet dan Plastik, 28(1), 50-58.

Sah, N. K. (2013). Greener approach to leather techniques (Thesis). Kokkola, India: Centra University of Applied Sciences.

Sarwono, J. (2013). IBM SPSS Advanced Statistik. Yogyakarta, Indonesia: Penerbit Andi.

Suryaningsih, P. E., Heryanto, H., Mursulasno, M., \& Nainggolan, K. (2007). Pembuatan kulit jadi dengan berbagai type finish untuk atasan sepatu (upper leather). Yogyakarta, Indonesia: Balai Besar Kulit, Karet dan Plastik. 
